\title{
ANALYSIS OF TRADE SPECIALIZATION: INDONESIAN TOBACCO ON INTERNATIONAL MARKET
}

\author{
Wahib Muhaimin Abdul \\ Faculty of Agriculture, University of Brawijaya, Malang, Indonesia \\ E-mail: awmuhaimin@gmail.com
}

\begin{abstract}
Tobacco is Indonesian export commodities that seeded and expected to developed in order to have a market share in international market. Market share analysis is used to determine the Indonesian tobacco market share in international markets, or how many percentage of market domination, while the analysis of trade spezialiton index is used to determine whether Indonesia should be the state tobacco exporter or importer of tobacco. If the ISP value $\geq 0.5$, then Indonesia tend to be exporters of tobacco. Meanwhile, when the value obtained ISP $<0.5$ to close to 0 , then Indonesia tend to be importers of tobacco. Based on the analysis of market share, Indonesia has a market share better than the French and Thailand. The average of Indonesian market in the period $2000-2014$ was $2.30 \%$, while France is $1.61 \%$ and Thailand is $1.45 \%$. Then based on the analysis ISP, Indonesia is capable of being tobacco exporting countries due to the value of more than 0.5 ISP. Based on the analysis, we can conclude that Indonesia's market share is better than France and Thailand, furthermore in the future Indonesia will continue to be tobacco exporting countries in the world.
\end{abstract}

\section{KEY WORDS}

Tobacco, market share, trade specialization market, ISP.

Indonesia is one of the countries that embrace open economy, embracing some strategies such as export development program, especially non-oil exports. The purpose of non-oil export development program in Indonesia is to support efforts to increase the global competitiveness of Indonesian products and increase export role in spurring economic growth in Indonesia (Firmansyah, 2008).

Plantation sector is one sector which is the main program of Indonesia in export development program (Qineti, 2013; Rokhmah, 2014). One of the commodities which become unreliable Indonesian export commodities according to the Directorate General of Plantation Crops (2014) is tobacco.

Tobacco is a commodity of Indonesia that is prioritized to be developed in a period of agricultural development in the future (Indonesian Tobacco Farmers Association) (ITFA, 2015. This can be proofed, until 2014 tobacco industry still plays a role in the wheel movements of the national economic, especially in tobacco-producing areas and central of the tobacco industry, by growing industrial/related services, providing business field and employment (Central Bureau of Statistics, 2015).

The condition of increasing acreage as in 2008 to 2014 , showed that tobacco has potential condition to be developed (Directorate General of Plantation Crops, 2014).

The amount of tobacco exports depend on the amount of tobacco production produced in the country (Table 1).

Until 2011 Indonesia still included to tobacco exporting countries in the world. A total of 38905 tonnes of tobacco successful to be export from the domestic tobacco production amounted to 214524 tonnes, only 16 percent are exported from the production quantities of tobacco produced in the country. On the table shows that the number of Indonesian tobacco production more than the number of French tobacco production and Thailand, but the condition is different from Indonesia, 31 percent of the tobacco exported from the amount of tobacco produced by French production and as much as 15 percent of the amount of tobacco exported tobacco production produced by Thailand. 
Table 1 - Tobacco Exporters countries in the International Market

\begin{tabular}{llc}
\hline \multirow{2}{*}{ Country } & \multicolumn{2}{c}{ 2011 (ton) } \\
\cline { 2 - 3 } Brazil & Production & Export \\
United States of America & 1.516 .204 & 533.579 \\
Zimbabwe & 432.217 & 187.020 \\
China, mainland & 177.704 & 134.466 \\
India & 5.028 .355 & 223.791 \\
Malawi & 1.321 .994 & 188.223 \\
Argentina & 278.619 & 159.842 \\
Turkey & 230.950 & 80.618 \\
Italy & 71.674 & 68.031 \\
Mozambique & 130.885 & 61.232 \\
France & 111.493 & 52.734 \\
Indonesia & 71.585 & 22.851 \\
Thailand & 214.524 & 38.905 \\
\hline
\end{tabular}

Therefore, fluctuations in the tobacco productions and tobacco exports will affect the amount of comparative advantage and which has been owned by Indonesia, both directly and indirectly (Haynes et al, 2013). These conditions will affect the competitiveness of Indonesia tobacco exports in the international market (Hadi et al, 2008). If these conditions are not immediately respond, then the decrease of Indonesian tobacco exports would affect the competitive position of tobacco Indonesia in the international market, while an increase in tobacco imports will reduce foreign exchange earnings for the country, one of this has been generated from the export of tobacco (Bernatonyte and Normantiene, 2009); Caporale and Sova, 2015).

The development of tobacco exports happened because of weak competitiveness of Indonesian tobacco in the world tobacco market (Shohibul, 2013). Considering the increasing competition, in which the countries producers and exporters of tobacco is now able to improve the performance of its products, it is essential to identify tobacco Indonesia's competitiveness in the international market. If the position of the tobacco Indonesia's competitiveness in the international market has been identified it is important also to know the position of Indonesia as a country specialization importer or exporter of tobacco. The aim of this study was to control of the market or the Indonesian market for tobacco.

\section{RESEARCH METHODOLOGY}

The data used in this study are secondary data (time series) for 15 years 2000 to 2014 . This study uses data export and import of tobacco. Data taken from the relevant departments such as the Central Bureau of Statistics, the Food Agricultural Organization (FAO), and the Directorate General of Estate Crops.

This study used two analyzes. The first is an analysis to determine the market share of each country, Indonesia, Thailand and France. According to Salvatore (1997), Bernatonyte et al (2013) mathematical equation about tobacco market share can be written as follows:

$$
\text { PPElit }=\left(\frac{\text { QXlit }}{Q W w i t}\right) \times 100 \%,
$$

Where:

- PPElit:market share commodity export in the country in the international market at year $t(\%)$.

- QXlit:commodity export quantity I in country i in year t (tonnes).

- QXwit:total export commodities volume on the international market in the year $t$ (tonnes).

The second is the analysis of trade specialization index (ISP), which is used to determine whether to tobacco, Indonesia tend to be exporters or importers (Sallatu, 2006; Ernster et al, 2000). 
Tambunan (2003) and Burger (2001) explains that the mathematical equation of the ISP can be written as follows:

$$
\mathrm{ISP}=\frac{\mathrm{Xi}-\mathrm{Mi}}{\mathrm{Xi}+\mathrm{Mi}},
$$

Where:

- ISP:Trade Specialization Index

- Xi:Indonesian tobacco exports

- Mi:Indonesia tobacco imports

This calculation results range is between $0-1$. If the ISP value $\geq 0.5$, then Indonesia tend to be exporters of tobacco. Meanwhile, when the value obtained ISP $<0.5$, close to 0 , then Indonesia tend to be importers of tobacco.

\section{RESULTS AND DISCUSSION}

Analysis of Indonesian Tobbaco Market Share in the International Market. Based on the results and discussion on market share analysis, obtained from the quantity of tobacco. Exports's producing countries compared to the total volume of exports of the world's tobacco (Hadianto, 2009). These results and discussion shows that Indonesian tobacco exports in the international market better than France and Thailand, with the average value each country's average is 2.30 percent, 1.61 percent, 1.45 percent.
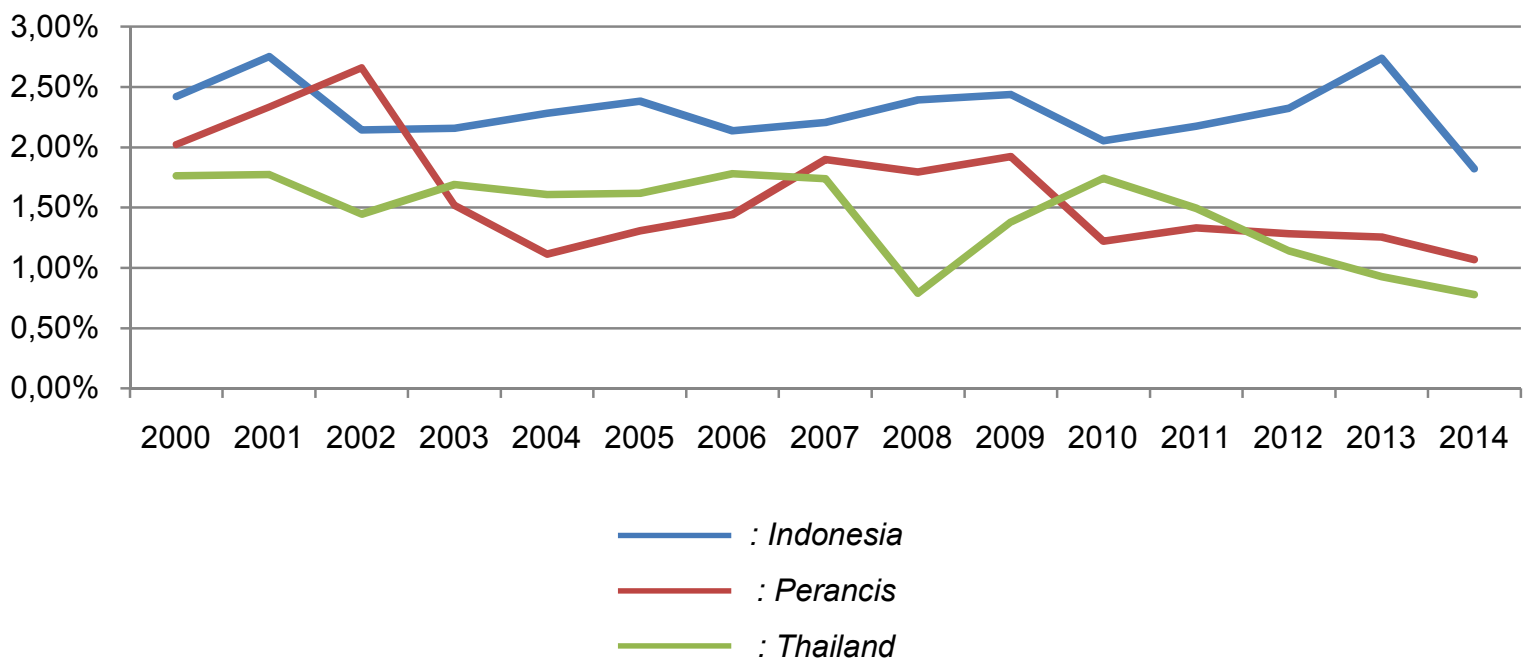

Figure 1 - Graph Export Tobacco Market Share of 3 Export Countries in the International Market

The position of the largest market share of Indonesia occurred in 2001 at 2.75 percent, better than France which only amounted to 2.33 percent and Thailand amounted to 1.78 percent. This shows that in 2001, Indonesia has a market share of the tobacco at 2.75 percent of the total world tobacco exporter. It shows the positive things when compared with competitor countries Indonesia in this study, namely France and Thailand, each of that country has particularly market share or market power of 2.33 and 1.78 percent.

In the following year, Indonesia had experienced fluctuations in world tobacco market share, example in 2002 to 2008 . But in 2009 , the Indonesian market to bounce back with a value market share of 2.44 percent. It did not last long, in the period of the next year, Indonesia experienced a decline in market share. This decrease is exactly what happened in 2014.

Several factors that make the fluctuations of Indonesian tobacco market share are the quantity of production, consumption, and domestic tobacco land area has decreased and 
increase (Porter, 1993). Then other factors that make Indonesian tobacco market share decline are the increasing amount of exports of tobacco exporting countries.

Analysis of Indonesian Tobbaco Trade Specialization Index. Djafar (2013) and Djorović (2012) stated, analysis of Trade Specialization Index (ISP) is used to determine whether a state in the tobacco commodities should perform the import or export. In the other words, whether the country should be the exporter or the importer.

Based on the analysis of tobacco Trade Specialization index, it can be said Indonesia could become an exporter of tobacco country. Indonesian ISP value that indicates the number is always greater than 0.5 means that Indonesia both in terms of exports of tobacco.

Table 2 - Indonesian Tobacco Trade Specialization Index

\begin{tabular}{lc}
\hline Year & ISP Value \\
\hline 2000 & 0,53 \\
2001 & 0,56 \\
2002 & 0,55 \\
2003 & 0,52 \\
2004 & 0,50 \\
2005 & 0,53 \\
2006 & 0,50 \\
2007 & 0,51 \\
2008 & 0,58 \\
2009 & 0,56 \\
2010 & 0,54 \\
2011 & 0,61 \\
2012 & 0,60 \\
2013 & 0,57 \\
2014 & 0,51
\end{tabular}

Sources: Directorate General of Plantation Crops, 2014

Indonesia has a ISP value more than 0.5 due to the import factor of Indonesia's tobacco, therefore can be said that the quantity of import is less that the quantity of exports. It can be said Indonesia could become tobacco exporter country.

\section{CONCLUSION AND SUGGESTION}

The domination market or market share of Indonesia 's tobacco is fluctuated. This is caused by the quantity of factors of production, consumption, and domestic tobacco land area has decreased and increas and also export from competitor countries.

Based on the tobacco trade specoalization Index, Indonesia could become a tobacco exporter country because tobacco ISP premises value is more than 0.5 .

Needed to improve the domestic tobacco production to support Indonesian tobacco exports in the international market through programs associated with it.

The following studies should be done using the analysis to find out what are the factors that influence the Indonesian tobacco market share and the factors that influence the export of Indonesian tobacco.

\section{REFERENCES}

1. Bernatonyte, D. Burksaitiene, D. \& Rimiene, K. (2013). Trade Specialization Pattern of Lithuania. Economics and Management: 2013. 18 (4).

2. Bernatonyte, D. \& Normantiene, A. (2009). Estimation of Trade Specialization: the Case of the Baltic States. Ekonomika-Engineering Economics (2).

3. Burger, K. Kameo, D. \& Sandee, H. (2001). Clustering of Small Agro-Processing Firms in Indonesia. International Food and Agribusiness Management Review, 2(3/4): 289-299.

4. Caporale, G. M. \& Sova, R. (2015). Trade Flows And Trade Specialisation: The Case Of China. Working Paper No. 15-07.

5. Central Bureau of Statistics (2015). Yield tobacco industry. Accessed in october 2015. 
6. Directorate General of Plantation Crops. (2014). Varieties Superior Tobacco In East Java as an Effort To Improve The Quality Of Seeds. PBT Ahli Muda BBPPTP. Surabaya.

7. Djafar, D. (2013). Analysis of the market segment of in coconut palm, cocoa, rubber, and coffee indonesia on the international market. Brawijaya University, Malang.

8. Djorović, M. Stevanović, S. \& Lazić, V. (2012). The World And Domestic Markets For Tobacco And Tobacco Products1. Economics of Agriculture. (59) 1 (21-35).

9. Ernster, V. Kaufman, N. Nichter, M. Samet, J. \& Yoon, S. Y. (2000). Women and tobacco: moving from policy to action. Bulletin of the World Health Organization.

10. Firmansyah, (2008). The Position of Competitiveness and Specialization Trading of Tea Indonesia in Facing Globalization.Brawijaya. University. Malang.

11. Food And Agricultural Organization (FAO). (2015). The state exporters commodities tobacco.

12. Hadi, P. U. Kustiari, R. \& Anugrah, I. S. (2008). Case Study of Tobacco Cultivation and alternate in Indonesia. Indonesian Center for Agricultural Socio-Economic and Policy Studies, Department of Agriculture. Jakarta.

13. Hadianto. (2009). The devices and investment model analysis on the international. Jakarta: Gramedia.

14. Haynes, J. Cubbage, F. Mercer, E. \& Sills, E. (2012). The Search for Value and Meaning in the Cocoa Supply Chain in Costa Rica. Sustainability, 4, 1466-1487

15. Indonesian Tobacco Farmers Association (ITFA), (2015). Tobacco as major commodities.

16. Porter, M. E. (1993). Excellence compete create and maintain. Erlangga. Jakarta.

17. Rokhmah, D \& Khoiron. (2014). Risk Factor Analysis of Green Tobacco Sickness (GTS) and the handling method on Tobacco Farmers. 20-29.

18. Shohibul, A.M.A. (2013). Revealed Comparative Advantage Measure: ASEAN-China Trade Flows. Journal of Economics and Sustainable Development. Vol.4, No.7.

19. Tambunan, T. H. (2003). The development of the agricultural sector in indonesia some important issue. Ghalia Indonesia, Jakarta. 